\title{
MOTIVATIONAL DIALOGUE AS A MODERN METHOD IN PRACTICAL SOCIAL WORK
}

\author{
Andrii Malesyk $k^{1}$, Marta Kozak ${ }^{2}$ \\ Lviv Polytechnic National University, Lviv, Ukraine \\ ${ }^{1}$ Student of master program "Social Work", of Department of Sociology and Social Work, \\ ${ }^{2}$ Ph. D., Associate Professor, of Department of Sociology and Social Work
}

Background: One effective form of counseling designed to help people change is motivational dialogue. By applying the principles of motivational dialogue, it is possible to increase the effectiveness of the social worker's influence when it is necessary to motivate clients to stop unemployment, to break the cycle of violence and to change their lives, if it is necessary to apply therapy for various addictions, to initiate any changes that will contribute to improvement. this or that situation. On the other hand, an empathetic form of motivational dialogue reduces the strain on the work of the social worker, preventing his or her professional burnout. Considering the above, we consider it expedient to analyze the possibility and expediency of the use of motivational dialogue in the practice of providing social services to families who find themselves in difficult life circumstances.

Purpose: to analyze the possibility of using motivational dialogue as a modern method in practical social work.

Methods: In the study of the theoretical basis for the use of motivational dialogue in social work with families, who were in difficult life circumstances, used scientific methods, including analysis of the available base of scientific sources, synthesis and synthesis of information obtained. Application of content analysis gave us the opportunity after systematization and generalizing information to draw your own conclusions.

Results: Motivational dialogue is a form of counseling designed to help people change. Motivational interviewing is defined as a collaborative and human-centered form of leadership to gain and enhance motivation for change. That is, this method focuses on directing people to a particular development vector and motivating them to become better through dialogue.

This approach deviates from traditional counseling concepts that focus on passive listening to the client, consciously focusing on the changes that the client can implement on their own. During the motivational dialogue session, the consultant seeks to increase the strength of the client's expressed motivation to change the target behavior and to reduce resistance to change (Miller, W. and Rollnick, S., 2009).

Conclusions: Therefore, motivational dialogue is a modern tool for practical social work that enables active listening not only to identify problems and needs of the client of social services, but also to motivate him to change. The introduction of this form of counseling will help improve the quality of the services provided, as well as build trust in the institution of social services as a whole.

Keywords: motivational dialogue, social work, practical application, family, children, teenagers, addicted person.

Одним із фундаментальних принципів сучасної моделі надання професійної соціальної допомоги є використання будь-яких контактів 3 клієнтом 3 метою формування у нього мотивації до змін, що є ключовим у подоланні життєвих труднощів.

На важливість налагодження позитивних відносин 3 клієнтом у максимально стислі терміни звертають увагу у своїх роботах Agnieszka Ignasiak, Elżbieta Olber та інші (Ignasiak A. \& Olber E, 2014).

Однією 3 ефективних форм консультування, розробленою з метою допомагати людям змінитися, є мотиваційний діалог. Застосовуючи засади мотиваційного діалогу, можна підвищити ефективність впливу соціального працівника у випадку необхідності мотивування клієнтів для припинення безробіття, до розірвання циклу насилля і зміни свого життя, у випадку необхідності застосування терапії від різного роду узалежнень, для ініціювання будь-яких змін, що сприятимуть покращенню в тій чи іншій ситуації. 3 іншого боку, емпатична форма мотиваційного діалогу зменшує напруження у роботі соціального 
працівника, запобігаючи його професійному вигоранню. Враховуючи викладене, вважаємо доцільним проаналізувати можливість та доцільність застосування мотиваційного діалогу у практиці надання соціальних послуг сім'ям, які опинились в складних життєвих обставинах.

Метою роботи $\epsilon$ проведення аналізу можливості застосування мотиваційного діалогу як сучасного методу у практичній соціальній роботі.

У дослідженні теоретичного підгрунтя для застосування мотиваційного діалогу у соціальній роботі з сім'ями, які опинились в складних життєвих обставинах були використані загальнонаукові методи, зокрема аналіз доступної бази наукових джерел, синтез та узагальнення отриманої інформації.. Застосування контент-аналізу дав нам можливість після систематизації та узагальнення відомостей зробити власні висновки.

Згідно результатів дослідження, мотиваційний діалог $\epsilon$ формою консультування, розробленою з метою допомагати людям змінитися. Визначається мотиваційне інтерв'ю як спільна та орієнтована на людину форма керівництва для отримання та посилення мотивації змін. Тобто, цей метод зосереджується на тому, аби 3 допомогою діалогу направити людину на певний вектор розвитку та мотивувати стати кращою.

Такий підхід відхиляється від традиційних концепцій консультування, орієнтованих на пасивне слухання клієнта, свідомо орієнтуючись на зміни, які клієнту під силу впровадити самотужки. Протягом сеансу мотиваційного діалогу консультант прагне збільшити силу вираженої мотивації клієнта до зміни цільової поведінки та зменшити опір до змін (Miller, W. and Rollnick, S., 2009).

Метод мотиваційного діалогу сьогодні застосовується на практиці у багатьох напрямках, хоча найчастіше у сфері боротьби із різного роду залежностями, де прагнення підвищення ефективності слугувало первинною причиною розвитку методу як такого. Проте, практика застосування методу демонструє результати, що дозволяють порівнювати його 3 методами 3 інших сфер практичної роботи соціальних працівників. Так, наприклад, у Великобританії, Польщі почав зростати інтерес до даного методу зі сторони сфери соціальної роботи щодо захисту дітей.( Miller, W. and Rollnick, S. 2009, Jamroży, 2018). Основні напрямки практичного застосування методу мотиваційного діалогу, такі як: мотиваційне інтерв'ю у роботі з сім'ями, дітьми та молоддю, а також з особами із залежністю висвітлюють у своїх роботах 3 кінця минулого століття багато науковців даної сфери, проте першими дослідниками прийнято вважати Міллера та Ролльника. (Forrester, D., Westlake, D. and Glynn, G., 2012).

Особливістю методу мотиваційного діалогу $є$ те, що за його практичного застосування, людина несе безпосередню відповідальність за дієвість методу та підсумкові результати. Це стає можливим якраз завдяки формі діалогу, у якій клієнт усвідомлює, що він $\epsilon$ безпосереднім учасником процесу, і не має змоги перекласти усю відповідальність на «авторитет спеціалістів». Саме цей прийом являється ключовим у застосуванні методу. Мотиваційний діалог зазвичай застосовується на етапі виявлення спектру проблем, формуванні цілей соціальної роботи з клієнтом а також опрацювання та впровадження плану роботи. Особливість цього методу полягає в тому, що соціальний працівник не вказує на конкретні розв'язки проблеми, а допомагає клієнтові зрозуміти існуючі проблеми та опрацювати цілі та план діяльності, спрямований на подолання життєвих труднощів.

При реалізації мотиваційного інтерв'ю соціальний працівник має декілька основних задач:

- необхідно вводити в розмову потрібні тези таким чином, щоби це мало вигляд нових життєвих принципів для людини;

- $\quad$ соціальний працівник має контролювати поведінку клієнта, задаючи уточнюючі питання (наприклад, перед тим, як дати пораду) - це дозволяє зберігати позитивне русло діалогу;

- потрібно задавати відкриті питання, відзначати попередні прикладені зусилля людини, постійно аналізувати те, що вона говорить, а також іії поведінку.

Не дивлячись на потенційно абсолютно різні ситуації та обставини у житті людей, що звертаються по допомогу у соціальні служби, при роботі з такими людьми з використанням цього методу головним $є$ постановка закритих та відкритих запитань, застосування більш м'якої 
або грубої манери ведення діалогу, а також постійний аналіз того, що говорить людина у відповідь. Так завдяки цьому аналізу можна виділити два основних «сценарії» розмови.

Різниця між цими сценаріями досить велика, і у першому випадку можна припустити, що клієнт у підсумку може залишитися з почуттям тиску, але без будь-якої реальної мотивації змінитись, тоді як у другому випадку можна розраховувати на те, що людина почуватиметься вислуханою і може задуматися над тим, чому вона насправді робить ті чи інші речі/має залежність від алкоголю, тютюну чи наркотичних речовин, i, можливо, навіть подумає про те, що може змінитися у іiі житті, як би вона могла змінитися (Miller, W. and Rollnick, S., 2002).

Варто відзначити, що є докази, які підтверджують те, що людина при другому «сценарії» мотиваційного діалогу набагато частіше самостійно звертається до соціальних організацій для подальшої допомоги та підтримки, тоді як людина у першому випадку може цього не робити, і навіть активно уникати нових дискусій з працівником соціальної служби.

Проаналізувати, наскільки вдало реалізовуються ідеї та принципи мотиваційного діалогу можна, записуючи розмову з людиною (звичайно, з їі дозволу) і просто слухаючи, відзначивши, коли задавалися відкриті чи закриті запитання, коли без дозволу надавалися поради, і де підкреслювалася самостійність людини в ході мотиваційного діалогу (David Wilkins, 2014).

Таким чином, доцільно наголосити, що мотиваційний діалог є сучасним інструментом практичної соціальної роботи, що дає змогу за допомогою активного слухання не просто виявити проблеми та потреби клієнта соціальних послуг, а i вмотивувати його до змін. Впровадження такої форми консультування сприятиме підвищенню якості послуг, що надаються, а також зміцненню довіри до інституту соціальних служб в цілому.

\section{References}

David Wilkins, (2014). Motivational Interviewing: An Evidence-Based Approach to Working with Families. Retrieved from https://socialworkhelper.com

Forrester, D., Westlake, D. \& Glynn, G. (2012). Parental resistance and social worker skills: towards a theory of motivational social work. Child and Family Social Work, 17(2), 118-129.

Ignasiak, A., Olber, E., Maciejewska-Dłubała, M., Kubiak-Horniatko, M., (2014). Narzędzia pracy socjalnej, http://www.wrzos.org.pl/download/NPS_2701.pdf

Jamroży, K., (2018) Dialog motywujący jako współczesnametoda pracy socjalnej z rodziną z problemem alkoholowym. Nová sociálna edukácia človeka VII Medzinárodná interdisciplinárna vedecká konferencia, Preńov, 6. 11. 2018., 286-301.

Miller, W. \& Rollnick, S., (2002). Motivational Interviewing: Preparing People for Change. Second edition. London: The Guilford Press.

Miller, W. \& Rollnick, S., (2009). Ten things that Motivational Interviewing is not. Behavioural and Cognitive Psychotherapy, 37(2), 129-140.

Połeć, M., (2012). Transteoretyczny Model Zmiany - towarzysz Dialogu Motywującego, [w:] J. M. Jaraczewska, I. Krasiejko (red.), Dialog Motywujacy w teorii i praktyce. Motywowanie do zmiany w pracy socjalnej i terapii, Wyd. Edukacyjne Akapit, Toruń, ISBN 978-83-89163-943.

\footnotetext{
Контактна інформація:

Козак Марта Ярославівна m_fedyk@yahoo.com

Малесик Андрій Вікторович andrijmalesik@gmail.com
} 